\title{
RELEVANSI PEMBIAYAAN PEMILIKAN RUMAH (PPR) SYARIAH TERHADAP PENYELESAIAN PEMBIAYAAN BERMASALAH BERNILAI HUMANIS ISLAMI
}

\section{RELEVANCE OF SHARIA HOME OWIERSHIP FINANCING (PPR) TO COMPLETION OF PROBLEMED FINANCING WITH VALUE OF ISLAMIC HUMANIC}

\author{
Kurnaemi Anita \\ Sekolah Tinggi Ilmu Islam dan Bahasa Arab (STIBA) Makassar \\ Email: kurnaemi.aa@stiba.ac.id \\ Muhammad Wahyuddin Abdullah \\ Pascasarjana UIN Alauddin Makassar \\ Email: wahyuddin.abdullah@uin.alauddin.ac.id

\section{Muhammad Nirwan Idris} \\ Sekolah Tinggi Ilmu Islam dan Bahasa Arab (STIBA) Makassar \\ Email: muhammadnirwan@stiba.ac.id
}

Keywords:
Relevance, Sharia Property,
Problemed Financing, Islamic
Humanic

\section{Keywords :}

Humanic

\begin{abstract}
Preference in solution construction of non-performing financing based on Islamic business ethics was born from the accumulation of figh of muamalah conceptions. This study aimed to describe the PPR mechanism according to sharia standards and to identify the relevance of sharia PPR practices in producing non-performing financing with Islamic humanist values based on fiqh of muamalah. This is qualitative research with a phenomenological approach to the Sharia Property Developer PT Wahana Persada Indonesia. Data collection was conducted through observation and interviews with the president director, accounts receivable staff, marketing staff, and several users. This research describes the flow of financing that occurs in the field, starting from the location survey to the implementation of the Sale and Purchase Agreement and the handover of homeownership certificates. Besides, this study also finds three types of handling of problematic financing qualifications applied by developers in each cluster, starting from soft connections, restructuring, and finding a replacement for users. This is then made relevant to the values of Islamic business ethics to create an Islamic humanist financing atmosphere.
\end{abstract}

\section{Kata kunci :}

Relevansi, Properti Syariah, Pembiayaan Bermasalah, Humanis Islam

\footnotetext{
Preferensi dalam konstruksi penyelesaian pembiayaan bermasalah (NonPerforming Financing) berdasarkan etika bisnis Islam lahir dari akumulasi konsepsi fikih muamalah. Penelitian ini bertujuan untuk menggambarkan mekanisme PPR sesuai standar syariah dan menemukan relevansi antara ptaktik PPR Syariah dalam melahirkan penyelesaian pembiayaan bermasalah bernilai humanis Islami berasas fikih muamalah.
} 


\begin{abstract}
Penelitian ini adalah penelitian kualitatif dengan pendekatan fenomenologi pada Developer Properti Syariah PT Wahana Persada Indonesia. Pengumpulan data dilakukan dengan observasi dan wawancara terhadap direktur utama, staf piutang, staf marketing, dan beberapa user. Penelitian ini menjabarkan alur pembiayaan yang terjadi di lapangan, mulai dari survei lokasi hingga pelaksanaan Akad Jual Beli (AJB) sampai serah terima sertifikat kepemilikan rumah. Selain itu, penelitian ini juga menemukan tiga jenis penanganan terhadap kualifikasi pembiayaan bermasalah yang diterapkan pihak developer pada setiap klasternya, mulai dari soft connection, restrukturisasi hingga mencari user pengganti. Hal ini kemudian direlevasikan terhadap nilainilai etika bisnis Islam sehingga melahirkan atmosfir pembiayaan bernilai humanis Islami.
\end{abstract}

Diterima: 27 September 2020; Direvisi: 22 Oktober 2020; Disetujui: 26 Oktober 2020; Tersedia online: 18 Desember 2020.

How to cite : Anita, K., Abdullah, M. W., Idris, M. N. (2020). Relevansi Pembiayaan Pemilikan Rumah (PPR) Terhadap Penyelesaian Pembiayaan Bermasalah Bernilai Humanis Islam. NUKHBATUL 'ULUM: Jurnal Bidang Kajian Islam, 6(2), 159-186. https://doi.org/10.36701/nukhbah.v6i2.221

\title{
PENDAHULUAN
}

Pembiayaan merupakan penyediaan dana atau tagihan yang dipersamakan dengan transaksi bagi hasil dalam bentuk mudārabah, dan musyārakah, sewa menyewa dalam bentuk ijārah atau sewa beli dalam bentuk ijārah muntahiya bittamז k, jual beli dalam bentuk piutang murābahah, salam dan istiṣnā', pinjam meminjam dalam bentuk piutang qard, dan sewa menyewa jasa dalam bentuk ijārah untuk transaksi multijasa ${ }^{1}$. Istilah pembiayaan berdasarkan prinsip 'kepercayaan' berarti lembaga pembiayaan selaku șạibul māl menaruh kepercayaan kepada seseorang untuk melaksanakan amanah yang diberikan. Dana tersebut harus digunakan dengan benar, adil, dan harus disertai dengan ikatan dan syarat-syarat yang jelas dan saling menguntungkan bagi kedua belah pihak $^{2}$.

Lebih jauh Kusumawati, Nurhayanto, Beik mengemukakan bahwa sistem pembiayaan yang diterapkan pada Lembaga Keuangan Syariah memiliki beberapa perbedaan dengan sistem pemberian kredit yang diterapkan pada lembaga konvensional. Perbedaan tersebut antara lain terletak pada akad atau perjanjian, pembagian keuntungan, dan besarnya persentase dana yang harus dikembalikan oleh debiturnya ${ }^{3}$. Pembiayaan syariah dituangkan dalam suatu perjanjian/akad yang mempunyai peranan dalam pembiayaan yang menjadi dasar

${ }^{1}$ Undang-Undang RI Nomor 21 Tahun 2008 Tentang Perbankan Syariah dalam https://www.bphn.go.id/data/documents/92uu007. Diakses pada 17 Desember 2019.

${ }^{2}$ Veithzal Rivai dan Andria Permata Veithzal, Islamic Financial Management (Raja Grafindo Persada: Jakarta, 2008), h. 3.

${ }^{3}$ Nidaa Nazahah Kusumawati, Nunung Nuryartono, dan Irfan Syauqi Beik, "Analisis Pembiayaan Dan Kredit Sektor Konstruksi di Indonesia; Studi Perbankan Syariah Dan Konvensional", Jurnal Ekonomi Dan Kebijakan Pembangun, 6 No. 1 (Juli 2017): h. 22. 
dalam aktivitas pembiayaan tersebut ${ }^{4}$. Hal inilah yang disebutkan oleh Iskandar dan Aqbar bahwa dalam praktik ekonomi Islam, bukan hanya keuntungan semata yang dikejar, akan tetapi perlu mengindahkan aturan syariat Islam ${ }^{5}$, terlebih dalam akad pembiayaan.

Dalam dasawarsa terakhir kemudian muncul Lembaga Keuangan Syariah non-bank yang menyediakan pembiayaan properti syariah. Secara spesifik, properti syariah atau perumahan berlabel syariah tidak dikenal dalam peraturan Undang-Undang Nomor 1 Tahun 2011 tentang Perumahan dan Kawasan Permukiman (UU No. 1/2011). Label 'syariah' sehubungan dengan perumahan adalah berkaitan dengan sistem pembiayaan perumahan, sebagaimana dalam ketentuan Pasal 121 UU 1/2011 yang menyatakan bahwa pemerintah dan/atau pemerintah daerah harus melakukan upaya pengembangan sistem pembiayaan untuk penyelenggaraan perumahan dan kawasan permukiman ${ }^{6}$. Sedangkan Pembiayaan Pemilikan Rumah (PPR) dikatakan sesuai dengan prinsip syariah dalam ekonomi Islam ketika telah sesuai dengan beberapa syarat, yaitu: pertama, tidak merugikan satu sama lainnya, artinya selama pihak pembeli tidak merasa keberatan atas angsuran yang ditentukan oleh pihak pemberi pembiayaan, maka jual beli dengan cara pembiayaan tersebut diperbolehkan. Namun, jika justru menambah beban bagi si pemilik rumah, maka jual beli dengan cara pembiayaan tersebut tidak diperbolehkan; ; Kedua, jual beli kredit tersebut tidak mengandung unsur-unsur yang melanggar hukum Islam ${ }^{8}$; Ketiga, dalam jual beli kredit tidak ada niat dari salah satu pihak untuk merugikan pihak lain ${ }^{9}$. Selain itu, juga harus terbebas dari unsur darar (bahaya) dan jahālah (ketidakjelasan/spekulatif).

\section{Skema Akad Pembiayaan Pemilikan Rumah (PPR) Syariah}

Secara global, minat terhadap properti syariah terus mengalami peningkatan dalam 10 tahun terakhir terutama dipicu semakin bertambahnya

${ }^{4}$ Lukmanul Hakim, Amelia Anwar, "Pembiayaan Murabahah Pada Perbankan Syariah Dalam Perspektif Hukum dI Indonesia”, AL-URBAN: Jurnal Ekonomi Syariah dan Filantropi Islam 1, No. 2 (Desember 2017): h. 213.

${ }^{5}$ Azwar Iskandar, \& Khaerul Aqbar, "Reposisi Praktik Ekonomi Islam: Studi Kritis Praktik Ekonomi Islam di Indonesia”, NUKHBATUL 'ULUM: Jurnal Bidang Kajian Islam 5, no 1 (2019): h. 39 .

${ }^{6} \mathrm{https}: / /$ www.hukumonline.com/klinik/detail/ulasan/lt5e0d68d141b79/bolehkahperumahan-menerapkan-hukum-syariah-/. Diakses pada 20 Februari 2020.

${ }^{7}$ Seperti: MAGRIB, singkatan dari Maisir (judi), Aniaya (semena-mena), Garar (penipuan), Haram, Riba (bunga), Iktinaz (menimbun barang) atau Ikhtikar (monopoli), dan Batil. Lihat: Marhamah Saleh, "Pasar Syariah dan Keseimbangan Harga", Jurnal Media Syariah, 8 No. 1 (2011): h. 25.

${ }^{8}$ Muhammad Hanif, "Islamic mortgages: principles and practice", International Journal of Emerging Markets, 14 No. 5 (July 2019): h. 2.

${ }^{9}$ Afrida Putritama, "Penerapan Etika Bisnis Islam Dalam Industri Perbankan Syariah", Nominal, Barometer Riset Akuntansi dan Manajemen, 7 No. 1 (April 2018): h. 2. 
masyarakat muslim ${ }^{10}$. Lebih jauh lagi, Firmansyah dan Indika mengungkapkan bahwa properti syariah non-bank lebih banyak diminati karena dinilai berbeda dengan KPR biasa dengan intermediasi perbankan. PPR syariah non-bank dipercaya lebih memudahkan pelanggan karena pelanggan tidak harus berurusan dengan hal administratif yang sering kali membebani ${ }^{11}$. PPR syariah non-bank dianggap memiliki fleksibilitas tinggi karena memiliki berbagai fitur sebagai berikut; tidak ada BI checking, tidak memerlukan slip gaji atau SK sehingga cocok untuk para pengusaha nonformal (seperti para pedagang), tanpa sita, tanpa denda, dan tanpa riba. Beberapa fitur tersebut menjadi nilai jual bagi para pengembang yang disampaikan melalui media promosi seperti website atau media sosial ${ }^{12}$. Skema PPR syariah non-bank dianggap lebih sederhana dan lebih fleksibel dari sisi mekanisme pembiayaan karena tidak melibatkan intermediasi perbankan atau lembaga keuangan lainnya. Pihak ketiga yang dilibatkan dalam transaksi adalah notaris yang berperan melegalkan transaksi secara hukum.

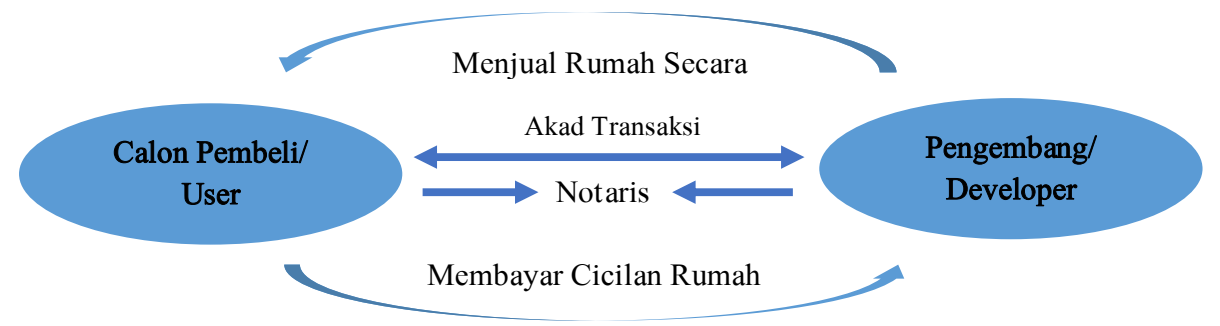

\section{Gambar 1. Skema PPR Syariah}

Skema di atas menunjukkan alur mekanisme pembiayaan yang terjadi pada Developer Properti Syariah pada umumnya, mulai dari kesepakatan akad transaksi yang digunakan hingga pencatatan di pihak notaris sebagai jaminan berbadan hukum setelah melakukan pengajuan kontrak jual beli. Sementara skema akad pembiayaan yang dipraktikkan pada PPR syariah baik pada Lembaga Keuangan Syariah atau lembaga non-bank pada umumnya adalah menerapkan akad bai al-taqsīt (بيع التقسيط) yang secara etimologi berarti "الحصة و النصيب atau

${ }^{10}$ Michael Lipka, "Muslims and Islam: Key Findings in The U.S. and Around The World", Pew Research Center, Washington, DC, USA, August 9, 2017. https://www.pewresearch.org/facttank/2017/08/09/muslims-and-islam-key-findings-in-the-u-s-and-around-the-world/. Diakses pada 27 Juli 2020

${ }^{11}$ Egi Arvian Firmansyah \& Deru R Indika , "Kredit Pemilikan Rumah Syariah Tanpa Bank: Studi di Jawa Barat", Jurnal Manajemen Teori dan Terapan, 10 no. 3 (Desember 2017): h. 226.

${ }^{12}$ Munadi Idris, "Implementasi Pembiayaan Pemilikan Rumah (PPR) Syariah Studi Kasus Pada Griya Ar-Roya Di Kota Makassar", Tesis (Makassar: Ekonomi Syariah UIN Alauddin, 2014), h. 3. 
bermakna membagi sesuatu menjadi beberapa bagian ${ }^{13}$. Sedangkan secara terminologi, Wahbah al-Zuhail mendefinisikannya sebagai:

مبادلة أو بيع ناجز, بتم فيه تسليم المبيع في الحال, و يؤجل وفاء الثمن أو تشديده. كله أو بعضه إلى آجل معلومة في

Artinya:

"Aktivitas jual beli yang sah ketika ada proses penyerahan barang, walaupun menunda pembayaran pada waktu yang disepakati di kemudian hari."

Secara sederhana, bai'ut taqsiț (kredit) dapat dideskripsikan dengan seseorang yang membeli barang tertentu untuk dimanfaatkan, kemudian bersepakat dengan penjual dalam pelunasan pembayaran dengan cara cicil/kredit dalam jangka waktu tertentu ${ }^{15}$. Secara umum, jual beli dengan sistem kredit diperbolehkan oleh syariat. Hal ini berdasarkan pada beberapa dalil, di antaranya adalah firman Allah swt. dalam Qs. Al-Baqarah/2: 282,

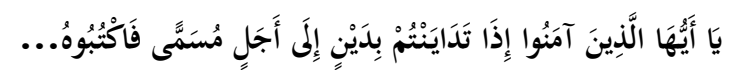

Terjemahnya:

"Hai orang-orang yang beriman, apabila kamu bermuamalah tidak secara tunai untuk waktu yang ditentukan, hendaklah kamu menuliskannya"16.

Ayat ini menjadi dalil legalitas akad utang-piutang, di mana akad kredit merupakan salah satu bentuk utang sehingga keumuman ayat bisa menjadi dasar bolehnya akad kredit. Begitu pun yang termaktub dalam hadis Āisyah,

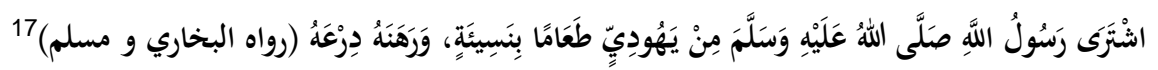

Artinya:

"Rasulullah saw. membeli sebagian bahan makanan dari seorang Yahudi dengan pembayaran tempo dan beliau juga menggadaikan perisai kepadanya".

Dalam hadis ini Rasulullah saw. membeli bahan makanan dengan sistem pembayaran tempo yang semisal dengan kredit. Meskipun secara prinsip jual-beli kredit diperbolehkan, ada sejumlah poin penting yang perlu diperhatikan bagi praktisi jual beli kredit, di antaranya: Pertama, objek jual beli bukan komoditi

\footnotetext{
${ }^{13}$ Muhammad bin Mukrim bin Manżūr, Lisānul 'Arab, Jilid 7 (t. Cet; Beirut: Dar Shadir, 1433 H/ 2010 M), h. 377.

${ }^{14}$ Wahbah bin Mușțafā al-Zuhailī, al-Mu'āmalāt al-Māliyah al-Mu'āṣirah (Cet. 1; Beirut: Dar al-Fikr, 1423 H/ 2002 M), h. 311.

${ }^{15}$ 'Isā bin Ibrāhīm al-Duwaisī, Al-Buyuu' al-Jaa-izu Minhaa wa al-Mamnuu'.

${ }^{16}$ Departemen Agama RI, al-Qur'ān dan Terjemahnya (Cet. 17; Jakarta: Darus Sunnah, 2002), h. 9.

${ }^{17}$ Muhammad bin Ismā'̄îl bin Ibrāhīm al-Bukhārī, Șaḥịh al-Bukhārī (Cet. I; Kairo: Dār Ibnu al-Jauzī, 1431 H/ 2010 M), h. 287. Lihat juga: Muslim bin al-Ḥajjāj al-Naisābūrī, Șaḥịh Muslim (Cet. I; Kairo: Dār Ibnu al-Jauz̄̄, 1431 H/ 2010 M), h. 110.
} 
ribawi yang sejenis dengan alat tukar ${ }^{18}$; Kedua, tidak terjadi penundaan serah terima barang dalam akad kredit, karena hal ini merupakan praktik jual beli utang dengan utang. Artinya, barang masih berada dalam tanggungan penjual dan uang masih berada dalam tanggungan pembeli. Inilah praktik jual beli dain bid dain yang disepakati keharamannya oleh para ulama ${ }^{19}$. Diriwayatkan dalam sebuah hadis dari Ibnu 'Umar bahwa,

$$
\text { أن البي صلى الله عليه و سلم فهى عن بيع الكالئ بالكالئ (رواه الحاكم) }
$$

Artinya:

\section{"Bahwa Nabi saw. melarang jual beli hutang dengan hutang."}

Ibnu Hajar mengungkapkan bahwa mayoritas ulama menilai hadis ini lemah dari sisi sanad ${ }^{21}$. Meskipun demikian, mereka sepakat menerima kandungan maknanya, sebagaimana pernyataan Ibnul Munżir yang dinukilkan oleh Ibnu Qudāmah bahwa para fuqaha sepakat atas keharaman jual beli utang dengan utang. Lebih jauh lagi, Imam Ahmad bahkan mengatakan bahwa hal ini merupakan ijmak kaum muslimin ${ }^{22}$.

Salah satu segmen yang juga populer digunakan dalam PPR syariah adalah akad isitșnā $\bar{a}^{\prime 23}$. Akad istișnā' biasanya dipraktikan pada pembiayaan perbankan syariah dan properti syariah dalam proyek konstruksi ${ }^{24}$. Secara istilah, istiṣna ' adalah suatu akad yang dilakukan produsen dengan pihak pemesan untuk mengerjakan sesuatu sebagaimana tertera pada akad perjanjian. Fatwa Dewan Syariah Nasional MUI juga menyatakan bahwa akad istișnā 'merupakan akad jual beli dalam bentuk pemesanan pembuatan barang tertentu dengan kriteria dan persyaratan tertentu yang disepakati antara pemesan (mustași ${ }^{\prime}$ ) dan pembuat $\left(s \bar{a} n i^{i}\right)^{25}$. Dalam hal ini, pemesan membeli suatu barang yang dibuat oleh

\footnotetext{
${ }^{18}$ Majma' al-Fiqh al-Dauli pada Daurah Mu’tamar al-Islami, Tentang “al-Bai’ bi al-Taqșiṭ”, Jeddah, Kerajaan Saudi Arabia,17-23 Sya'bān 1410 H. http://www.iifa-aifi.org/1785.html

${ }^{19}$ Muwaffaquddīn Ibnu Qudāmah, al-Mugnī, Jilid 3 (Cet. 3; Dar 'Alam al-Kutub, 1417 H/ 1997 M), h. 306.

${ }^{20}$ Muhạammad bin 'Abdillāh Al-Hākim al-Naisābūrī, al-Mustadrak 'Alā Șaḥịhain, Jilid 2 (Cet. 2; Beirut: Dar al-Kutub al-'Ilmiyyah, 1422 H/ 2002 M), h. 40.

${ }^{21}$ Imam Ibnu Hajar dalam Talkhīṣ al-Habīr menukilkan pendapat para pakar hadis seperti Aḥmad bin Hanbal dan al-Syāfi'I yang melemahkan hadis ini. Lihat: Aḥmad bin 'Alī Ibnu Hajar al-Asqalān̄i, Talkhīṣ al-Habìr fì Takhrīj Ahạdīis al-Rāfi' al-Kabìr, Jilid 3 (Cet. 1; Kairo: Muassasah al-Qurțūbah, 1416 H/ 1995 M), h. 62

${ }^{22}$ Muwaffaquddīn Ibnu Qudāmah, al-Mugn̄̄, Jilid 3, h. 306.

${ }^{23}$ Muhammad Rizki Hidayah, Kholil Nawawi,dan Suyud Arif, "Analisis Implementasi Akad Istishna Pembiayaan Rumah (Studi Kasus Developer Property Syariah Bogor)”, Jurnal Ekonomi Islam, 9 No. 1 (Mei 2018): h. 9.

${ }^{24}$ Usma Rachamadi, Produk dan Akad Perbankan Syraiah di Indonesia (Cet. 1; Bandung: PT Citra Aditya Bakti, 2009), h. 197.

${ }^{25}$ Dewan Syariah Nasional Majelis Ulama Indonesia, Himpunan Fatwa Dewan Syariah Nasional (Cet. 2; Jakarta: MUI Pusat, 2003), h. 36.
} 
produsen, di mana pekerjaan atau penyelesaian pesanan ada pada pihak produsen $^{26}$.

Kebanyakan ulama mazhab Hanafiyah dan ahli fikih kontemporer beranggapan bahwa istișna ' adalah akad yang diperbolehkan dan halal ${ }^{27}$. Lebih jauh ulama mazhab Malikiyah dan syafi'iyah beranggapan bahwa akad istișnā merupakan bentuk akad salam, sehingga mereka menegaskan akad ini boleh dijalankan bila memenuhi berbagai persyaratan akad salam ${ }^{28}$, yaitu bila pihak pemesan tidak mendatangkan bahan baku, maka berbagai persyaratan salam harus dipenuhi. Akan tetapi jika pihak mustași mendatangkan bahan baku, maka yang terjadi adalah jual/sewa jasa dan bukan salam, maka berbagai persyaratan pada akad sewa jasa harus dipenuhi, di antaranya yang berkaitan dengan tempo pekerjaan dan jumlah upah ${ }^{29}$. Adapun al-Bābartī mendeskripsikan skema akad istiṣnā' sebagai berikut:

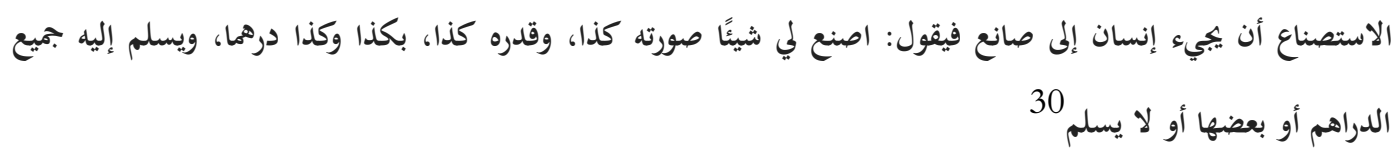

Arinya:

"istịsnā" adalah akad di mana seorang mustạnni datang kepada șāni" dan berkata: buatkan untukku suatu barang dengan spesifik begini, sebanyak ini, dengan bahan ini, dan seharga ini. Kemudian ia membayar șāni' secara tunai, atau setengah pembayaran, atau dengan mengakhirkan pembayaran."

Pradipta, Roziq, Maria juga menambahkan gambaran praktik jual beli dalam properti syariah yang dilakukan oleh Lembaga Keuangan Syariah atau lembaga properti syariah non-bank dilakukan oleh pihak produsen dengan pihak pemesan dengan akad istiṣnā untuk membuatkan atau mengerjakan sebuah konstruksi rumah atau bangunan di mana pemesan membeli konstruksi yang dibuat oleh produsen, sedangkan bahan dan jasa bersumber dari pihak produsen dan harus dilakukan menurut standar syariah ${ }^{31}$.

\footnotetext{
${ }^{26}$ Wahbah bin Mușṭafā al-Zuhailī, al-Fiqh al-Islāmī wa Adillatuhu (Cet. 2; Damaskus: Dar al-Fikr, 1432 H/ 2011 M), h. 342.

${ }^{27}$ Muhammad bin 'Abdil Wāḥid al-Askandarī Ibnul Humām, Syarh Fathul Qadīr 'Alā Hidāyatu Syarh Bidāyatul Mubtad̄̄, Jilid 7 (Cet. 1; Beirut: Dar al-Fik, 1432 H/ 2010 M), h. 114.

${ }^{28}$ Muḥammad bin 'Abdirraḥmān al-Mālikī al-Khațțāb, Mawāhibul Jal̄̄l fì Syarh Mukhtașar al-Syaikh Khalīl, Jilid 4 (Cet. 1; Damaskus: Dar al-Rị̣wān, 1431 H/ 2015 M), h. 514. Lihat juga: Abu Zakariyyā Yaḥyā bin Syaraf al-Nawawī, Rawḍatu al-Ṭālibīn wa 'Umadatul Muftīn, Jilid 4 (Cet. 3; Riyad: al-Maktabah al-Islāmiyyah, 1412 H/ 1991 M), h. 26. 26.

${ }^{29} \mathrm{Abu}$ Zakariyyā Yahyā bin Syaraf al-Nawawī, Rawḍtu al-Ṭālibīn wa 'Umdatul Muftīn, h.

${ }^{30}$ Muhammad bin Muhammad al-Bābartī, al-'Ināyah Syarh al-Hidāyah, Jilid 7 (t.Cet; Beirut: Dar al-Fikr, t.th), h. 114.

${ }^{31}$ Himawan Pradipta, Ahmad Roziq, Siti Maria, "Implementation of Istishna Contract in Sharia Developer (Case Study on Lukasya Land Properti)", International Journal of Sciense and Rresearch, 7 no. 7 (July 2018), h. 357.
} 


\section{Pembiayaan Bermasalah (Non-Performing Financing)}

Ironisnya, banyak terjadi penyimpangan dalam praktik PPR dengan skema syariah oleh para pengembang atau developer sehingga masih perlu diadakan tinjauan ulang dalam mekanisme transaksinya, khususnya dalam proses penyelesaian pembiayaan bermasalah. Pembiayaan bermasalah atau NonPerforming Financing (NPF) merupakan rasio pembiayaan bermasalah terhadap total pembiayaan, yaitu pembiayaan yang kualitasnya berada dalam golongan kurang lancar, diragukan, dan macet ${ }^{32}$. Pembiayaan bermasalah menurut kualitasnya didasarkan atas risiko terhadap kondisi dan kepatuhan nasabah dalam memenuhi kewajiban menyerahkan nominal bagi hasil serta melunasi pembiayaannya ${ }^{33}$.

Damanhur, dkk. menyatakan bahwa risiko pembiayaan bermasalah (NPF) tidak hanya terjadi pada Lembaga Keuangan non-bank, di mana hal ini juga banyak menimpa Perbankan Syariah ${ }^{34}$. Bahkan menurut Mutawali, Perbankan Syariah memiliki tingkat rasio Non-Performing Financing yang lebih tinggi dibanding Bank Konvensonal karena dipicu oleh beberapa faktor ${ }^{35}$. Lebih jauh lagi, Ascarya menjelaskan bahwa salah satu faktor yang memicu terjadinya pembiayaan bermasalah dapat dikategorikan dalam faktor internal dan eksternal, baik yang disebabkan oleh nasabah maupun pihak bank itu sendiri sehingga harus dicegah dengan penerapan manajemen risiko yang terstandarisasi syariah ${ }^{36}$.

Dalam upaya mengakomodir permasalahan ini, maka dibutuhkan sebuah prinsip syariah agar pelaksanaan usaha tidak semata-mata mencari keuntungan dan mengesampingkan etika dan moral, akan tetapi berusaha mengelaborasi seluruh aspek sehingga mendapatkan hasil yang tidak merugikan salah satu pihak. Zaroni juga menambahkan bahwa prinsip syariah merupakan penerapan etika bisnis dalam syariat Islam, yakni mengedepankan akhlak dalam menjalankan bisnis sesuai dengan nilai-nilai Islam dan sebagai rambu dalam melakukan transaksi agar tetap berjalan dalam koridor syariah, sehingga dalam melaksanakan bisnisnya tidak perlu ada kekhawatiran sebab diyakini sebagai sesuatu yang baik dan benar ${ }^{37}$. Sementara upaya penanganan yang dilakukan oleh Lembaga Keuangan Syariah atau Lembaga Properti Syariah terkadang masih dijumpai beberapa praktik muamalah yang tidak sesuai dengan kode etik syariah

\footnotetext{
${ }^{32}$ Muhammad Syafi'i Antonio, Bank Syariah Dari Teori ke Praktik (Jakarta: Gema Insani Press, 2001), h. 50

${ }^{33}$ Trisadini P. Usanti, Transaksi Bank Syariah, (Jakarta: PT Bumi Aksara, 2013), h. 105.

${ }^{34}$ Damanhur, et al, "What is the Determinant of Non-Performing Financing in Branch Sharia Regional Bank in Indonesia", Emerald Reach Proceedings Series, 1 (2018): h. 269.

${ }^{35}$ Mutawali, Ahmad Rodoni, Muhammad bin Said, "Prevention Effectiveness of NonPerforming Financing in the Indonesian Islamic Bank", Etikonomi, 18 No. 2 (2019): h. 259.

${ }^{36}$ Ascarya, Akad dan Produk Bank Syariah (Jakarta: PT Raja Grafindo Persada, 2008), h.91.

${ }^{37}$ Akhmad N. Zaroni, "Bisnis dalam Perspektif Islam (Telaah Aspek Keagamaan Dalam Kehidupan Ekonomi”, Mazahib, 4 No. 2 (2007): h. 127-142.
} 
sehingga menyebabkan kerugian dan kezaliman terutama pada pihak nasabah atau user. Salah satunya contohnya ketidaksiapan operator perbankan syariah menanggung risiko kerugian dari skema mudarabah. Hal ini menjadi indikasi bahwa akad yang terjalin antara pihak perbankan dan nasabah bukan mudarabah akan tetapi akad utang piutang yang berbunga ${ }^{38}$.

Berdasarkan hal tersebut, artikel ini menyajikan hasil temu lapangan yang dilakukan pada salah satu unit usaha sector real yang menawarkan Pembiayaan Pemilikan Rumah (PPR) syariah di Kota Makassar yaitu Developer Properti Syariah PT. Wahana Persada Indonesia dengan konsep rumusan masalah sebagai berikut: (1) Bagaimana mekanisme pembiayaan yang diterapkan oleh Developer Properti Syariah PT. Wahana Persada Indonesia?; (2) Bagaimana relevansi PPR yang dipraktikkan oleh pihak developer terhadap penyelesaian pembiayaan bermasalah bernilai humanis Islami berbasis fikih muamalah?. Penelitian ini bertujuan untuk memaparkan dan menerangkan mekanisme pembiayaan yang diterapkan oleh Developer Properti Syariah PT. Wahana Persada Indonesia, kemudian menganalisis dan mengungkap relevansi PPR yang dipraktikkan oleh phak developer terhadap penyelesaian pembiayaan bermasalah bernilai humanis Islami berbasis fikih muamalah.

Penelitian ini merupakan penelitian kualitatif analisis dengan pendekatan fenomenologi yaitu sebuah pendekatan dengan menggunakan interaksi simbolik (simbolic interaction) dan membangun teori berdasarkan pengumpulan data tentang suatu fenomena yang menjadi fokus penelitian ${ }^{39}$. Lokasi penelitian yaitu Developer Properti Syariah PT. Wahana Persada Indonesia sebagai unit usaha pengembang (sector real) dengan skema syariah yang mencoba memberikan kemudahan kepada masyarakat agar dapat memenuhi kebutuhan tempat tinggal dengan konsep jual beli sesuai standar syariah. Data diperoleh langsung dari subjek penelitian sebagai sumber informasi yang dicari terdiri dari Direktur Utama, Staf Marketing dan Staf Piutang, serta beberapa user PT. Wahana Persada Indonesia.

Penelitian tentang penyelesaian pembiayaan bermasalah (NPF) pada Pembiayaan Pemilikan Rumah (PPR) oleh Lembaga Keuangan Syariah non-bank masih sangat terbatas sehingga pada penelitian ini mencoba mengembangkan penelitian yang telah dilakukan oleh sejumlah peneliti terdahulu seperti penelitian yang dilakukan Madjid tentang penanganan pembiayaan bermasalah

${ }^{38}$ Muhammad Arifin Badri, Riba Dan Tinjauan Kritis Perbankan Syariah, (Gresik: Yayasan Al-Furqon Al-Islami, 2017), h. 174.

${ }^{39}$ Brian Kelleher Sohn, et al, "Hearing the Voices of Students and Teachers: A Phenomenological Approach to Educational Research", Qualitative Research in Education, 6 No. 2 (June 2017): h. 125. 
pada Bank Syariah ${ }^{40}$. Dalam penelitian tersebut penanggulangan pembiayaan bermasalah dapat dilakukan melalui penyelesaian oleh bank sendiri secara bertahap dengan pendekatan persuasif. Bila tahap pertama tersebut telah dilakukan, maka dapat digunakan langkah dan tahapan berikutnya antara lain penyelesaian melalui debt collector, penyelesaian melalui Kantor Lelang, penyelesaian melalui badan peradilan (al-qada), penyelesaian melalui Badan Arbitrase $(\operatorname{tah} k \bar{\imath} m)$ dan Penyelesaian melalui Direktorat Jenderal Piutang dan Lelang Negara (DJPLN) untuk bank-bank BUMN.

Kemudian penelitian yang dilakukan oleh Zulfikri, Sobari dan Gustiawati tentang strategi penyelamatan pembiayaan bermasalah pada pembiayaan murabahah Bank BNI Syariah Cabang Bogor ${ }^{41}$. Dalam penelitiannya, strategi pertama yang digunakan oleh Bank BNI Syariah Cabang Bogor yakni stay strategy atau dengan kata lain cooperative strategy, yang merupakan strategi di mana pihak bank masih ingin mempertahankan hubungan bisnis dengan nasabah dalam konteks waktu jangka panjang. Strategi ini dilaksanakan dengan menggunakan upaya-upaya restrukturisasi (seperti rescheduling, reconditioning, dan restructuring), yakni upaya perbaikan yang dilakukan oleh Bank BNI Syariah Cabang Bogor dalam rangka membantu nasabah agar dapat menyelesaikan kewajibannya, dengan tujuan penyelamatan pembiayaan sekaligus menyelamatkan usaha debitur agar sehat kembali.

Juga penelitian yang dilakukan oleh Firmansyah dan Gunardi mengenai sebuah temuan paradigma baru dalam Kredit Pemilikan Rumah pada Properti Syariah. Penelitian ini mengungkapkan salah satu permasalahan yang dihadapi Properti Syariah berupa tingkat kecurangan user karena tidak ada proses credit scoring sebagaimana yang dilakukan oleh perbankan ${ }^{42}$. Namun, dalam penelitiannya belum dipaparkan proses penanganan pembiayaan bermasalah oleh Properti Syariah berdasarkan paradigma tersebut sehingga masih perlu diadakan kajian lanjutan.

Artikel ini merupakan pengembangan dari penelitian terdahulu terkhusus yang disebutkan di atas dan merupakan penelitian baru dalam mengungkap praktik Pembiayaan Pemilikan Rumah (PPR) oleh Developer Properti Syariah dalam penyelesaian pembiayaan bermasalah bukan hanya dari aspek strateginya namun juga nilai-nilai Islam yang lahir dari pengimplementasiannya berdasarkan fikih muamalah.

\footnotetext{
${ }^{40}$ Sitti Saleha Madjid, "Penanganan Pembiayaan Bermasalah Pada Bank Syariah", J-HES Jurnal Hukum Ekonomi Syariah, 2 No. 2 (Desember 2018): h. 95.

${ }^{41}$ Ari Zulfikri, Ahmad Sobari, Syarifah Gustiawati, "Strategi Penyelamatan Pembiayaan Bermasalah Pada Pembiayaan Murabahah Bank BNI Syariah Cabang Bogor", Al-Maal; Journal of Islamic Economics and Bangking, 1 No. 1 (Juli 2019): h. 76-77.

${ }^{42}$ Egi Arvian firmansyah, Ardi Gunardi, "A New Paradigm in Islamic Housing: Non-Bank Islamic Mortgage", Al-Iqtishad: Journal of Islamic Economics, 10 No. 2 (July 2018): h. 313.
} 


\section{PEMBAHASAN}

\section{Mekanisme Pembiayaan Developer Properti Syariah PT. Wahana Persada Indonesia}

Dalam muamalah ada sejumlah prinsip dan kaidah yang diatur menurut syariat ${ }^{43}$. Salah satunya, dari perkataan 'Umar bin al-Khațāāb yang berbunyi: لَ (Tidak boleh berjualan di pasar kami kecuali orang yang paham tentang agama), hal ini mempertegas adanya aturan main dalam praktik muamalah yang wajib diketahui oleh setiap orang yang berkepentingan di dalamnya. Untuk itu, dipandang perlu menjabarkan sistem dan mekanisme pembiayaan yang dipraktikkan oleh pihak developer.

Tabel 1. Mekanisme Pembiayaan PT. Wahana Persada Indonesia

\begin{tabular}{cc}
\hline & Sistem Transaksi \\
\hline & Traksaksi 2 arah (developer dan user) \\
\hline Tidak menerapkan sistem jaminan \\
\hline Tidak memberlakukan denda \\
\hline Tidak menerapkan penalti \\
\hline Tidak menggunakan asuransi \\
\hline Tidak melakukan sistim sita \\
\hline Alur & Tidak mengadakan BI Checking \\
\hline & Tindakan \\
\hline
\end{tabular}

\begin{tabular}{|c|c|c|}
\hline Alur & Mekanisme & Tindakan \\
\hline 1 & $\begin{array}{l}\text { Survey dan Booking Fee } \\
(B F) / \text { Refundable }\end{array}$ & $\begin{array}{l}\text { User membayar BF sebagai tanda jadi atau keseriusan } \\
\text { untuk melanjutkan transaksi jual beli atau pembiayaan. } \\
\text { Nilai BF biasanya berkisar } 5-10 \text { juta rupiah, yang akan } \\
\text { include dalam down payment (DP) }\end{array}$ \\
\hline 2 & $\begin{array}{l}\text { Permohonan dan } \\
\text { pengajuan data user }\end{array}$ & $\begin{array}{l}\text { Tidak ada syarat khusus untuk calon user sebagaimana } \\
\text { yang diterapkan oleh perbankan. Semua akan ditentukan } \\
\text { melalui proses interview dan verifikasi terkait kelayakan } \\
\text { calon user. }\end{array}$ \\
\hline 3 & Interview dan verifikasi & $\begin{array}{l}\text { Developer menjelaskan tentang akad dan prosedur, } \\
\text { spesifikasi rumah, dan harga. Pihak developer akan } \\
\text { melakukan seleksi calon user yang ketat dan mendalam } \\
\text { dengan mengajukan kurang lebih } 40 \text { pertanyaan sebagai } \\
\text { alat untuk mengukur keseriusan dan karakter user. }\end{array}$ \\
\hline 4 & $\begin{array}{l}\text { Pembayaran Down } \\
\text { Payment (DP) }\end{array}$ & $\begin{array}{l}\text { User diminta melunasi kewajiban DP sebelum } \\
\text { terlaksananya akad jual beli. }\end{array}$ \\
\hline 5 & AJB & $\begin{array}{l}\text { Pihak user melunasi angsuran hingga akhir watu yang } \\
\text { disepakati untuk melakukan AJB dan penyerahan } \\
\text { sertifikat atas kepemilikan lahan atau rumah }\end{array}$ \\
\hline
\end{tabular}

Sumber: Data diolah tahun 2020

${ }^{43}$ Ismā’̄ll Khālidī, "al-Ḍawābiṭ wa al-Qawā'id al-Syar'iyyah li al-Mu'āmalah al-Māliyyah al-Islāmiyyah”, al-Hay’ah al-Syar'iyyah li Bank al-Kuwayti al-Turki (1422 H/ 2012 M), h. 2.

${ }^{44}$ Muhammad bin 'īsā al-Tirmiz̄î, Sunan al-Tirmizī, Juz 1 (Cet. 1; Riyad: Maktabah al'Ma'ārif, 1420 H/ 2000 M): h. 275. 
Alur dan mekanisme pembiayaan dimulai dari survei lokasi oleh user setelah penawaran melalui media sosial. User yang berminat pada lahan atau unit rumah diminta melakukan pembayaran $\mathrm{BF}^{45}$ dan DP berkisar antara 10-30\% dari harga unit sesuai kebijakan developer, include dengan nilai BF yang telah disetorkan di awal transaksi. Selanjutnya user diminta melunasi angsuran hingga akhir masa tenor yang disepakati. Selama masa angsuran, status kepemilikan rumah belum sepenuhnya menjadi milik user karena sertifikat kepemilikian rumah masih berada di pihak developer sebagai antisipasi terhadap hal-hal yang tidak diinginkan, disamping karena sertifikat atas lahan perumahan juga masih berstatus induk. Sertifikat atas rumah atau lahan dalam ketentuan PT. Wahana Persada Indonesia masih tertahan dan digantikan dengan kuitansi pembayaran hingga berakhirnya masa angsuran dan terlaksananya AJB, serta pajak pembeli berupa Bea Perolehan Hak atas Tanah dan Bangunan (BPHTB $)^{46}$.

Sistem pembiayaan yang diterapkan oleh PT. Wahana Persada Indonesia dari Tabel 1 menegaskan bahwa pihak developer hanya memberlakukan transaksi 2 arah, berbeda dengan Lembaga Properti lainnya yang melibatkan Bank sebagai pihak ketiga. Pihak developer juga tidak menerapkan sistem jual beli yang secara umum diterapkan oleh Lembaga Keuangan yang mengadakan PPR atau KPR seperti jaminan, denda, asuransi, sita, penalty, dan BI Checking ${ }^{47}$.

Lebih jauh Hasnawi menjelaskan bahwa pihak developer tidak menjadikan rumah yang sedang diangsur sebagai jaminan karena pada dasarnya rumah belum secara penuh dimiliki oleh $u s e r^{48}$. Begitu pun pengakuan Nur Aman tentang peniadaan BI Checking, user PT. Wahana Persada Indonesia sebagian besar berasal dari pedagang atau wirausahawan kecil dan menengah yang tidak memiliki izin usaha ${ }^{49}$. Hal ini menyebabkan susahnya menerapkan BI Checking sebagai salah satu upaya dalam manajemen risiko sebagaimana yang diterapkan oleh Lembaga Keuangan lainnya baik syariah maupun konvensional. Sementara akad pembiayaan yang diterapkan pihak developer adalah baiut taqsi untuk unit

\footnotetext{
${ }^{45}$ Nominalnya ditentukan oleh developer, yaitu 5-10 juta.

${ }^{46}$ Nur Aman Hammado, (45 tahun), Direktur Utama PT Wahana Persada Indonesia, Wawancara, 4 Maret 2020.

${ }^{47} \mathrm{BI}$ Checking merupakan sebuah istilah dari output yang dihasilkan oleh Sistem Informasi Debitur (SID). Sebutan resmi untuk BI Checking adalah Informasi Debitur Individual (IDI Historis) IDI Historis ini meliputi informasi seluruh penyediaan dana dengan kondisi bemasalah dal lancer mulai dari Rp. 1 ke atas. IDI Historis juga menampilkan info seputar riwayat pembayaran yang dilakukan dalam waktu 2 tahun terakhir. Lihat: Bank Indonesia, "Mengenai IDI Historis" dalam http://www.bi.go/id/id/moneter/biro-informasi-kredit/idihistoris/Contents/Default.aspx Diakses pada 4 Januari 2020.

${ }^{48}$ Hasnawi (45 tahun), Staf Piutang, Wawancara, 5 Maret 2020.

${ }^{49}$ Nur Aman Hammado, (45 tahun), Direktur Utama PT Wahana Persada Indonesia, Wawancara, 4 Maret 2020.
} 
yang sudah terbangun dan istiṣnā' untuk unit lahan yang belum atau sementara terbangun.

\section{Nilai-Nilai Islam dalam Pembiayaan Syariah}

Alam, dkk., dan Yusof menyebutkan bahwa sistem pembiayaan syariah (Islamic financing) yang dijalankan sesuai kaidah fikih muamalah akan melahirkan atmosfer pembiayaan yang bersifat humanis dan tidak zalim, di mana atmosfer ini dapat diukur dari keberadaan nilai-nilai Islam yang dirasakan dari praktik pembiayaan tersebut ${ }^{50}$. Sejalan dengan ini, Kasim juga menyebutkan bahwa para pelaku bisnis harus mematuhi syariat (shariah compliance) sehingga kepatuhan tersebut akan melahirkan quality management system yang sesuai dengan nilai-nilai Islam ${ }^{51}$. Adapun nilai-nilai ini dapat dijabarkan sebagai berikut:

Kemaslahatan. Maslahat disebut sebagai ri'āyah al-maqāṣid, karena dengan merealisasikan kemaslahatan berarti merealisasikan dan menjaga tujuan syariat ${ }^{52}$. Menurut istilah, kemaslahatan berasal dari kata mașlahah, yaitu mendatangkan segala bentuk kemanfaatan atau menolak segala bentuk kerusakan atau kemudaratan ${ }^{53}$. Manfaat adalah ungkapan dari seluruh kenikmatan yang diperoleh dari usaha yang telah dilakukan dan segala hal yang berhubungan dengan manfaat tersebut, sedangkan kerusakan adalah seluruh akibat yang merugikan atau segala sesuatu yang ada kaitannya dengan kerusakan tersebut ${ }^{54}$. Penerapan maslahah dan mafsadah ditentukan oleh kekuatan yang mendominasi dan banyaknya aktivitas yang dikerjakan. Jika manfaat lebih dominan dan kuat, maka disebut mașlahah, sebaliknya jika kerusakan lebih kuat dan mendominasi maka dikategorikan sebagai mafsadah ${ }^{55}$.

Menurut al-Fās, mașlạhah merupakan tujuan akhir yang ingin dicapai oleh syariat dan berbagai hikmah di balik setiap ketetapannya ${ }^{56}$. Kemudian alGazāli menegaskan bahwa mașlahah merupakan penjagaan terhadap tujuan

${ }^{50} \mathrm{Md}$. Mahmudul Alam, Chowdhury Shahed Akbar, et al, "The Islamic Shariah Principles For Investment in Stock Market”, Qualitative Research in Financial Markets, 9 No. 2 (2017): h. 2. Lihat juga: Kamaru Salam Yusof, "Practices in Islamic Finance; Between Islamic Fiqh and Flexibilty of Syariah”, Conference: Third Islamic Finance ConferenceAt: Sarajevo Bosnia, (November 2014): h. 3.

${ }^{51}$ Nor Aziah Abu Kasim, "Disclosure of Shariah compliance by Malaysian Takaful Companies", Journal of Islamic Accounting and Business Research, 3 No. 1 (July 2012): h. 21

${ }^{52}$ Muhammad bin 'Ali al-Syaukani, Irsyad al-Fuhul (Beirut: Dar al-Fikr, t.th), h. 156.

${ }^{53}$ Ibrāhīm bin Musā al-Syāṭib̄i al-I’tiṣām, Jilid 2 (Cet. 1; Kairo: Maktabah al-Tauhid, 1429 H/ 2008 M), h. 362.

${ }^{54}$ A. Syathir Sofyan, Salmah Said, Muhammad Wahyuddin Abdullah, "Financing Risk Measurement With Maqashid Al-Sharia Qualitative Risk", Share, 8 No. 1 (2019), h. 5.

${ }^{55}$ Ibrāhīm bin Mūsā al-Syāțibī, al-Muwāfaqāt fi Ușūl al-Syarī'ah, Jilid 2 (Cet. 1; Beirut: Dar alKutub al-Ilmiyyah, 1997), h. 20.

56،Allāl Al-Fāsī, Maqāșid al-Syarī'ah al-Islāmiyyah wa Makārimuha (Cet. 5; Dumyāṭ: Maktabah al-Wahdah al-arabiyyah, 1993), h. 10. 
syariat Islam yang terdiri dari lima poin krusial yang terangkum dalam maqāșid al-syāri' $a h^{57}$. Kelima poin tersebut merupakan konsep pertimbangan maslahat dalam menjaga agama, jiwa, akal, keturunan dan harta benda seseorang ${ }^{58}$. Dengan demikian, apa saja yang menjamin terjaganya kelima poin tersebut dinamakan dengan mașlahah dan setiap perkara yang merusaknya disebut mafsadah. Ungkapan mașlahah dan mafsadah merupakan bentuk yang masih umum, yang menurut jumhur ulama adalah mengarah pada hal-hal yang berhubungan dengan urusan dunia dan akhirat, dimana konsensus syariat diturunkan untuk kemaslahatan manusia di dunia dan akhirat secara bersamaan ${ }^{59}$.

Ukhuwah (Persaudaraan). Prinsip ukhuwah dibangun untuk menghindari terjadinya manipulasi dan miss communication dalam sebuah transaksi. Fauzia juga menyatakan bahwa prinsip ini menjembatani harmonisasi kepentingan beberapa pihak demi perolehan manfaat besama berdasarkan prinsip sharing economics $^{60}$. Hal ini karena suatu transaksi akan menjadi lancar dan terus berlangsung terutama dalam bidang bisnis karena tercipta kepercayaan antara penjual, pembeli, maupun perantara. Dalam subjektifitas perekonomian tidak ada yang dirugikan karena adanya rasa saling percaya dan mempunyai tanggung jawab terhadap bidangnya masing-masing. Selain itu, tidak ada manipulasi transaksional dalam praktik muamalah sehingga mendapatkan suatu keuntungan, dan tidak dianggap sebagai suatu kezaliman.

Rahman menyatakan bahwa hubungan antar individu dalam sistem ekonomi Islam cukup tersusun, sehingga saling membantu dan bersinergi serta lebih diutamakan daripada persaingan dan permusuhan sesama pelaku bisnis ${ }^{61}$. Ukhuwah sangat dibutuhkan dalam proses marketing yaitu pada public relations yang melibatkan banyak elemen masyarakat. Public relations memiliki gerak yang proaktif dan berorientasi masa depan, memiliki tujuan membangun, dan menjaga persepsi yang positif tentang kegiatan perekonomian di mata public ${ }^{62}$.

Keseimbangan. Nilai-nilai keseimbangan yang dimaksud merujuk pada konsep al-falāh(kejayaan) di dunia dan akhirat. Idri dan Baru menerangkan bahwa tidak ada pemisah antara kehidupan dunia dan akhirat, di mana setiap aktivitas manusia di dunia secara mutlak diyakini akan berdampak pada

${ }^{57}$ Abū Hāmid Muḥammad bin Muḥammad al-Ghazali, al-Mushtasyfa Min 'Ilmi al-Ușūl, Jilid 1 (Cet. 1; Beirut: Dār al-kutub al-'Ilmiyyah, 1413 H/ 1993 M), h. 7.

${ }^{58}$ Usman, M. H., Aswar, A., \& Irawan, A. W, "Syariat Islam dan Kemaslahatan Manusia di Era New Normal pada Kegiataan Keagamaan dan Pendidikan”, FENOMENA 12, no. 1 (2020): h. 94.

${ }^{59}$ Ibrāhīm bin Mūsā al-Syāțibī, al-Muwāfaqāt fi Ușūl al-Syarī‘ah, Jilid 2, h. 5.

${ }^{60}$ Ika Yunia Fauzia, "Perilaku Pebisnis dan Wirausaha Muslim dalam Menjalankan Asas Transaksi Syariah", JAMAL: Jurnal Akuntansi Multiparadigma, 9 No. 1 (April 2018), h. 39.

${ }^{61}$ Afazur Rahman, Doktrin Ekonomi Islam, Jilid 1 (t. Cet; Yogyakarta: PT Dhana Bhakti Wakaf, 1995), h. 23.

${ }^{62}$ Deny Riana, dkk, Spiritual Entrepeneur, (Bandung; MQS Publishing, 2008), h. 23. 
kehidupannya di akhirat, sehingga timbul upaya untuk berjalan sesuai koridor yang telah diatur dalam agama ${ }^{63}$. Hal ini tentu saja jauh berbeda dengan sistem kapitalis atau sosialis yang hanya berorientasi pada kehidupan dunia, sehingga ekonominya dibangun diatas kepentingan individu atau kelompok ${ }^{64}$. Keseimbangan dalam konsep kejayaan dunia dan akhirat hanya dapat dipenuhi jika keseluruhan aktivitas yang dilakukan manusia bertujuan untuk beribadah kepada Allah swt. Kesejahteraan dan kemakmuran tidak dijadikan sebagai tujuan hidup, namun ditujukan sebagai wasilah atau perantara untuk mewujudkan perintah Allah swt. ${ }^{65}$. Tujuan hidup yang hakiki hanyalah berpedoman pada nilainilai Islam, di mana semua hal tersebut untuk merealisasikan perintah Allah swt., sebagaimana dalam Qs. al-An'am/6: 162,

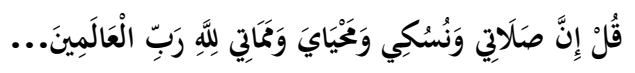

Terjemahnya:

"Katakanlah: Sesungguhnya sembahyangku, ibadahku, hidupku dan matiku hanyalah untuk Allah, Tuhan semesta alam"66.

Ayat ini menjelaskan tujuan penciptaan manusia di bumi, bahwa segala kerja dan usaha harus berorientasi ibadah. Kegiatan muamalah yang dilakukan bukan semata-mata untuk mengejar kesenangan dunia, namun diwajibkan untuk menyeimbangkannya dengan kepentingan akhirat berupa ketaatan bermuamalah dalam bingkai kode etik syariat.

Keadilan. Nilai keadilan merupakan pesan tekstual dari Al-Qur'an dan sunah yang tidak terpisahkan dari transaksi muamalah. Dalam Al-Qur'an, tidak kurang dari seratus ungkapan yang memasukkan gagasan keadilan, baik dalam bentuk kata-kata yang bersifat langsung maupun tidak langsung. Demikian juga di dalamnya ada dua ratus peringatan untuk melawan ketidakadilan atau semisalnya, di mana hal tersebut mencerminkan dengan tegas komitmen Islam terhadap keadilan ${ }^{67}$. Rahmat mengatakan bahwa keadilan dalam Al-Qur'an dibangun di atas prinsip keikhlasan, kesetaraan dan kejujuran, tidak terkecuali meliputi bidang ekonomi Islam ${ }^{68}$.

${ }^{63}$ Idri, Rohaizan Baru, "The Principles of Islamic Economics and their Implementation in Indonesia”, International Journal of Academic Research in Business and Social Sciences, 7 No. 4 (2017): h. 338.

${ }^{64}$ Muhammad Zeeshan Farrukh, "Capitalism, Globalization \& Islamic Economic Sistim”, Islamic Economics Journal, 1 No. 1 (2012): h. 74.

${ }^{65}$ Muhammad Akram Khan, "Methodology of Islamic Economics From Islamic Teachings to Islamic Economics", Turkish Journal of Islamic Economics, 5 No. 1 (March 2018): h. 48.

${ }^{66}$ Departemen Agama RI, al-Qur'ān dan Terjemahnya, h. 151.

${ }^{67}$ Majid Khadduri, The Islamic Conception of Justice (t. Cet; Maryland: The John Hopkins University Press, 1984), h. 1.

${ }^{68}$ Rahman, R. A., "Konsep Keadilan dalam Alquran", NUKHBATUL'ULUM: Jurnal Bidang Kajian Islam 2, no. 1 (2016): h. 174. 
Dalam hal aktivitas ekonomi, konsumsi, dan distribusi, Al-Qur'an menyebutkan larangan memakan harta dengan cara batil, dan perlunya peredaran kekayaan secara adil. Kata 'batil' menggambarkan segala sesuatu yang bertentangan dengan ketentuan dan nilai, dan distribusi kekayaan yang adil ${ }^{69}$ melukiskan nilai keseimbangan antara pribadi dan sosial. ${ }^{70}$ Sebagaimana firman Allah swt. dalam Qs. al-Baqarah/2: 188,

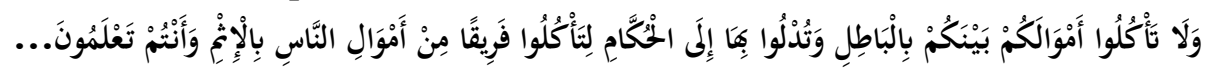

Terjemahnya:

"Dan janganlah sebahagian kamu memakan harta sebahagian yang lain di antara kamu dengan jalan yang batil dan (janganlah) kamu membawa (urusan) harta itu kepada hakim, supaya kamu dapat memakan sebahagian daripada harta benda orang lain itu dengan (jalan berbuat) dosa, padahal kamu mengetahui" ${ }^{\text {"1 }}$.

Ayat ini menegaskan akan haramnya memakan harta dengan cara yang haram, seperti korupsi, menipu, melakukan suap, riba, maysir, garar, ị̣tikār, dan perbuatan terlarang yang lain. Dengan demikian, upaya merealisasikan nilai-nilai keadilan Al-Qur'an dalam ekonomi dilakukan dengan menolak kompartementalisasi sekular dan kapital sehingga tercipta iklim muamalah yang bersifat humanis dan tidak zalim ${ }^{72}$.

\section{Relevansi Pembiayaan Pemilikan Rumah (PPR) Syariah dalam Penyelesaian Pembiayaan Bernilai Humanis Islami}

PT. Wahana Persada Indonesia memiliki penerapan standar kualifikasi pembiayaan khusus yang berbeda dengan standar kualifikasi perbankan. Hasnawi menjelaskan bahwa kualifikasi yang diterapkan oleh pihak developer terdiri dari: (a) pembiayaan lancar (kolektabilitas 1), berkisar antara 1-30 hari; (b) pembiayaan kurang lancar (kolektabilitas 2), berkisar antara 31-90 hari; dan (c) pembiayaan macet (kolektabilitas 3), berkisar antara 91-180 hari ${ }^{73}$. Masing-masing dari kualifikasi ini memiliki penanganan tersendiri dari pihak developer.

Menurut Hasnawi, penanganan kualifikasi pembiayaan pada kolektabilitas 1 cukup ditempuh dengan strategi soft connection, yaitu pengiriman surat pemberitahuan kepada pihak user atau dengan menelpon langsung untuk melakukan tabayun tentang kondisi user. Sedangkan pada kualifikasi pembiayaan

${ }^{69}$ Lihat: Qs. al-Hasyr/59: 7.

${ }^{70}$ Zakiyyuddin, Konsep Keadilan Dalam al-Qur'an, Disertasi (Yogyakarta: Pascasarjana UIN Sunan Kalijaga, 2006), h. 13.

${ }^{71}$ Departemen Agama RI, al-Qur'ān dan Terjemahnya, h. 30.

${ }^{72}$ Zakiyyuddin, Konsep Keadilan Dalam al-Qur'an, Disertasi, h. 14.

${ }^{73}$ Hasnawi (45 tahun), Staf Piutang, Wawancara, 5 Maret 2020. 
memasuki kolektabilitas 2 ditempuh dengan melakukan perubahan formasi pembayaran atau yang diistilahkan oleh pihak developer sebagai restrukturisasi.

Tabel 2. Konfigurasi Penyelesaian Pembiayaan Bermasalah.

\begin{tabular}{|c|c|c|c|}
\hline $\begin{array}{c}\text { Kualifikasi } \\
\text { Pembiayaan }\end{array}$ & $\begin{array}{l}\text { Waktu } \\
\text { (Hari) }\end{array}$ & Penanganan & Tindakan \\
\hline \multirow[t]{2}{*}{ Kolektabilitas 1} & \multirow[t]{2}{*}{$1-30$} & \multirow[t]{2}{*}{ Soft Connection } & $\begin{array}{l}\text { 1. Mengirim surat } \\
\text { pemberitahuan }\end{array}$ \\
\hline & & & 2. Menelpon \\
\hline \multirow[b]{2}{*}{ Kolektabilitas 2} & \multirow[b]{2}{*}{$31-90$} & \multirow[b]{2}{*}{ Restrukturisasi } & 1 Silaturahmi \\
\hline & & & $\begin{array}{l}\text { 2. Perubahan formasi } \\
\text { pembiayaan }\end{array}$ \\
\hline Kolektabilitas 3 & $91-180$ & Menawarkan user pengganti & \\
\hline
\end{tabular}

Dalam tahap ini, pihak developer akan melakukan silaturahmi dan observasi untuk mengetahui kondisi user dan memastikan keberlangsungan pembiayaan jika masih ada itikad baik dari pihak user. Tujuannya adalah untuk menyegarkan kembali pembiayaan dan menyelamatkan unit rumah yang telah diangsur. Tahapan ini memudahkan dan meringankan beban angsuran user karena nominal uang yang telah diangsur selama masa berjalan akan terhitung sebagai DP, sehingga nilai DP bertambah dan user sisa membayar kekurangan angsuran yang lebih ringan dengan jadwal angsuran (tenor) tetap seperti pada awal $\mathrm{akad}^{74}$.

Sementara untuk kualifikasi pembiayaan memasuki kolektakbilitas 3, pihak developer akan menawarkan pengalihan pembiayaan dengan mencari user pengganti dan melakukan proses pengembalian uang yang telah disetor oleh user pertama secara bertahap sesuai proporsinya setelah ditemukan user pengganti ${ }^{75}$. Ketiga tindakan ini dipadukan dengan kunjungan dan musyawarah bersama yang dilakukan berdasarkan asas kekeluargaan, di mana pihak developer berusaha memberikan edukasi dan pengertian kepada pihak user dalam mencari solusi terbaik, sehingga masing-masing pihak mendapatkan haknya dan tidak ada yang merasa terzalimi.

Adapun relevansi PPR PT. Wahana Persada Indonesia dalam melahirkan penyelesaian pembiayaan bermasalah bernilai humanis Islami berasaskan fikih muamalah dapat dijabarkan sebagai berikut: Pertama, relevansinya terhadap nilai maslahat. Adanya niat yang baik dari pihak developer dalam proses penyelesaian pembiayaan pada setiap klasternya dengan tujuan mencari solusi dan masalahat bersama sehingga tidak ada pihak yang merasa dizalimi, dan ini merupakan perwujudan dari nilai maslahat. Walaupun menurut Idrawati bahwa filter moral

\footnotetext{
${ }^{74}$ Nur Aman Hammado, (45 tahun), Direktur Utama PT. Wahana Persada Indonesia, Wawancara, 4 Maret 2020.

${ }^{75}$ Hasnawi (45 tahun), Staf Piutang, Wawancara, 5 Maret 2020.
} 
dan perilaku bisnis secara Islami merupakan hal yang wajar, dalam arti bahwa dalam pencapaian keuntungan guna memaksimumkan kesejahteraan perusahaan, maka dilakukan pada tingkat yang wajar dan terkendali, sehingga menghindari keuntungan yang berlebihan ${ }^{76}$. Tindakan ini merupakan norma perusahaan berlabel syariah, karena preferensinya adalah untuk nilai-nilai moral dan etika, bukan semata-mata disebabkan alasan ekonomi atau materi. Itulah sebabnya, tujuan bisnis Islami disebut maslahat, karena didasari oleh kebutuhan untuk mencapai kesejahteraan individu dan sosial.

Niat manajemen PT. Wahana Persada Indonesia dalam menjalankan transaksi muamalah sesuai nilai-nilai syariah merupakan pondasi amal yang dibingkai dalam proses penyelesaian pembiayaannya. Konsepsi ini diharapkan mampu melahirkan sebuah kemaslahatan yang dapat dirasa baik di dunia maupun di akhirat. Oleh karena itu, seluruh ajaran Islam dibangun di atas asas maslahat ${ }^{77}$, maka seluruh aktivitas ekonomi juga harus dibangun di atas prinsip tersebut. Salah satu prinsip Islam dalam muamalah adalah tậ̣sil al-maṣā lịh wa takmì lihā, wa ta'țīl al-mafâșid wa taqhilihā, yaitu mewujudkan maslahat dan memaksimalkannya, serta menghilangkan mudarat dan meminimalisirnya ${ }^{78}$. Di antara bentuk pengaplikasiannya adalah dengan memberikan pelayanan terbaik kepada konsumen untuk meraih maslahat bersama. Sebagaimana yang tampak dalam menangani kualifikasi pembiayaan pada kolektabilitas 2 yang ditempuh dengan menawarkan restrukturisasi.

Pada tahap ini pihak developer berusaha mencari solusi terbaik untuk mewujudkan kemaslahatan kedua pihak. Hasilnya tidak hanya dirasakan oleh pihak user, tapi juga dirasakan oleh pihak developer selama menjalankan transaksi muamalahnya berdasarkan nilai-nilai syariah yaitu berupa kepuasan dan kelancaran dalam manajemen dan bisnis. Diakui oleh pihak manajemen bahwa selama menangani pembiayaan user tidak banyak menemukan rintangan atau kendala yang berarti ${ }^{79}$. Fenomena ini kemudian dikonklusikan sebagai sebuah maslahat yang dirasakan oleh pihak developer selama menjalankan bisnis berbasis syariah.

Niat pihak developer melakukan transaski tanpa ribawi dan mengakomodir masyarakat muslim agar bisa mendapatkan rumah dengan cara

\footnotetext{
${ }^{76}$ Nur Khusniyah Indrawati, dkk,"Manajemen Risiko Berbasis Spritual Islam", Ekuitas: Jurnal Ekonomi dan Keuangan, 16 No. 2 (Juni 2012): h. 190.

${ }^{77}$ Berdasarkan perkataan al-Sa'dī 'الدين مبني على المصالح'Artinya: Agama dibangun di atas maslahat. Lihat: Sa'ad bin Nashir bin 'Abdul 'Aziz al-Syaṡri, Syarh Al Manzhumatus Sa'diyah fil Qowa'id Al Fiqhiyyah (Cet. 2; Dar Kanuz Isybiliya, 1426 H/ 2004 M), h. 12.

${ }^{78}$ Taqiyuddīn Abul 'Abbās Ibnu Taimiyyah, Majmū' al-Fatāwa, Jilid 10 (Cet. 1; Madinah: Majma’ Malik Fahd, 1425 H/ 2004 M) h. 512.

${ }^{79}$ Nur Aman Hammado, (45 tahun), Direktur Utama PT Wahana Persada Indonesia, Wawancara, 4 Maret 2020; Hasnawi (45 tahun), Staf Piutang, Wawancara, 5 Maret 2020.
} 
yang mudah dan terjangkau diyakini merupakan modal utama untuk mendapatkan pertolongan Allah swt. Berangkat dari niat baik ini maka kemudian diimplementasikan dalam bentuk muamalah bernilai syariah dalam bingkai kaidah fikih. Hasilnya, kemaslahatan yang dirasakan oleh kedua pihak yang bertransaksi sehingga melahirkan sebuah spirit muamalah yang bernilai Islami. Sebagai contoh jika user menunggak angsuran selama 6 bulan, harga rumah 175 juta, DP 5 juta dengan angsuran yang telah disetor sebanyak 29 juta, maka setelah restrukturisasi DP diakumulasi dengan angsuran yang telah disetor sehingga total DP menjadi 34 juta. Selanjutnya, 34 juta ini dianggap sebagai DP baru sehingga jumlah pembiayaan sisa 141 juta. 141 juta ini kemudian yang diangsur selama 96 bulan dikurangi 2 tahun (angsuran berjalan) sehingga angsuran menjadi lebih ringan ${ }^{80}$.

\section{Tabel 3. Komparasi Pembiayaan Hasil Restrukturisasi}

\begin{tabular}{cccc}
\hline No & Spesifikasi & Nilai transaksi awal & Nilai restrukturisasi \\
\hline 1. & Harga rumah & $175.000 .000,-(\mathrm{Rp})$ & $141.000 .000,-(\mathrm{Rp})$ \\
\hline 2 & DP & $5.000 .000(\mathrm{Rp})$ & $34.000 .000(\mathrm{Rp})$ \\
\hline 3 & Angsuran berjalan & $29.000 .000(\mathrm{Rp})$ & 0 (mulai dari awal) \\
\hline 4 & Waktu tenor & $96(\mathrm{bln})$ & $96($ bln)-2 thn \\
\hline
\end{tabular}

Sumber: Data diolah tahun 2020

Membandingkan Tabel 3 di atas dengan perlakuan Lembaga Keuangan Konvensional seperti perbankan dalam menangani NPF, pihak developer menawarkan solusi yang relevan dengan nilai kemaslahatan dalam arti user masih bisa mempertahankan unit rumah dan mendapat penyegaran pembiayaan karena jumlah angsuran yang telah disetor selama 2 tahun dikonstruk menjadi nilai DP baru, sehingga beban pembiayaan menjadi kurang dan menghasilkan angsuran yang lebih ringan.

Kedua, relevansinya terhadap nilai ukhuwah. Selanjutnya konsepsi penyelesaian pembiayaan bermasalah berasas mașlahah mafsadah telah memberikan framework ukhuwah yang terbina antara pihak developer dan pihak user. Praktik penyelesaian pembiayaan bernuansa kekeluargaan, mulai dari penggantian istilah 'surat peringatan' sebagaimana lazimnya yang diterapkan oleh perbankan atau perusahaan financing lainnya menjadi 'surat pemberitahuan', bermaksud untuk menjaga perasaan user. Kunjungan yang dilakukan dan musyawarah mufakat untuk melahirkan maslahat bersama yang diistilahkan oleh pihak developer sebagai 'soft connection' merupakan representatif nilai ukhuwah. Sebagaimana diterangkan Hasnawi jika ada user yang mengalami Non-Performing Financing, pihak developer tidak langsung

\footnotetext{
${ }^{80}$ Hasnawi (45 tahun), Staf Piutang, Wawancara, 12 Maret 2020.
} 
menerapkan istilah kolektabilitas, namun dilihat dulu historisnya untuk mengedepankan asas husnuzan ${ }^{81}$. Hal senada juga diakui oleh salah satu user PT. Wahana Persada Indonesia yang telah mengangsur selama 2 tahun dan mengalami gagal bayar selama 6 bulan ${ }^{82}$.

Nilai ukhuwah yang dikemas dalam bingkai silaturahmi oleh pihak developer dengan para user yang mengalami permasalahan pembayaran yaitu dengan membentuk jejaring supply chain yang mengarah kepada win-win solution atau asas manfaat bersama yang terus menerus dalam jangka panjang. Hal ini sesuai dengan salah satu alat kunci hasil penelitian Gilmore, dkk., yang mengatakan bahwa dua alat kunci yang digunakan untuk mengelola situasi yang berisiko adalah penggunaan kompetensi manajerial dan jejaring (networking) ${ }^{83}$. Pihak developer sadar bahwa dalam menjalankan praktik pembiayaan, ada tuntutan untuk senantiasa bersikap toleran terhadap user dalam bermuamalah dan melaksanakan haknya, agar bisa mengimplementasikan penyelesaian pembiayaan bernilai Islami. Dengan demikian, dari sisi ini, transaksi yang dibangun dapat merekatkan ukhuwah dua pihak yang terlibat dan diharap dapat tercipta hubungan yang senantiasa harmonis. Oleh karena itu, nilai ukhuwah yang terjalin tidak hanya dibangun oleh pihak developer sebagai pihak pemberi pembiayaan, namun pihak user juga berusaha untuk siqah (amanah) dalam menyelesaikan angsuran sesuai waktu yang telah disepakati ${ }^{84}$.

Ketiga, relevansinya terhadap nilai keadilan. Dalam menerapkan pembiayaan bernilai humanis Islami, prinsip yang harus dijunjung adalah tidak ada kezaliman yang dirasakan oleh pihak-pihak yang terlibat. Semua pihak harus rida dan adil sesuai takarannya, demi terciptanya prinsip 'an tarāọin minkum dalam transaksi muamalah. Kecurangan, manipulasi, ingin untung sendiri, atau hal-hal yang bersifat zalim seperti sita, denda, penalty, dan riba harus ditiadakan dalam transaksi PPR yang berkomitmen terhadap skema syariah.

Pada umumnya, perbankan akan menjalankan praktik manajemen risiko sesuai standar operasional yang terstandarisasi Otoritas Jasa Keuangan (OJK) seperti penerapan denda sampai sita, sehingga terkadang dinilai kurang adil oleh nasabahnya. Adapun user PT. Wahana Persada Indonesia merasakan kepuasan dalam bermuamalah dan sangat terbantu dengan adanya penyelesaian yang penuh toleransi sehingga nilai keadilan benar-benar terwujud. Implementasi nilai keadilan yang dilakukan oleh PT. Wahana Persada Indonesia adalah dengan

\footnotetext{
${ }^{81}$ Hasnawi (45 tahun), Staf Piutang, Wawancara, 12 Maret 2020.

${ }^{82} \mathrm{Nico},(30$ Tahun), User, Wawancara, 27 Maret 2020.

${ }^{83}$ Audrey Gilmore, Carson, dan A. O’Donnell, "Small Business Owner-Managers and Their Attitude to Risk", Marketing Intellegence and Planning, 22 No. 3 (2004): h. 349.

${ }^{84}$ Nur Aman Hammado, (45 tahun), Direktur Utama PT Wahana Persada Indonesia, Wawancara, 4 Maret 2020.
} 
menghindari unsur-unsur kezaliman, kecurangan, manipulasi, dan mengambil kesempatan dalam kesempitan yang terlihat dalam penanganan pembiayaan memasuki kolektabiltas 3, yaitu dengan pencarian user pengganti sebagai upaya memberikan hak masing-masing pihak sesuai proporsinya. Proses ini dinilai sebagai representative dari nilai keadilan di mana hak user berupa uang yang telah disetorkan selama masa angsuran akan dikembalikan secara bertahap setelah mendapat user pengganti. Hasilnya, lahir prinsip 'an taradin minkum antara pihak developer dan pihak user karena muamalah dilakukan di atas asas rida dan sukarela. Inilah prinsip fundamental dalam konsep pembiayaan syariah.

Keempat, relevansinya terhadap nilai keseimbangan. Selama ini kebanyakan perusahaan menggunakan nilai tambah atau profit hanya sebagai ukuran dalam menilai kinerja manajemen ${ }^{85}$. Singh menilai bahwa konsekuensi melihat kinerja manajemen hanya dari aspek ekonomi (uang/laba) saja menyebabkan banyak perilaku menyimpang terutama oleh pihak manajemen ${ }^{86}$. Hal senada juga diungkapkan Indrawati bahwa perilaku manajemen yang utilitarian kerap melanggar etika yang berlaku di masyarakat ${ }^{87}$. Komitmen pihak manajemen developer melakukan transaksi pembiayaan dibangun dalam bingkai fikih muamalah dengan tidak menjalankan praktik riba dengan skema denda, dan tidak menerapkan transaski zalim dengan skema sita dan penalty. Karena pada hakikatnya skema riba, sita dan penalty merupakan sebuah pelanggaran syariat dan kezaliman, dan seluruh pelanggaran syariat masuk dalam kategori mafsadah lawan dari mașlahah.

Hasil dari implementasi skema syariah dengan tujuan maslahat akan menghasilkan kebaikan di dunia dan pahala di akhirat. Kolaborasi skema muamalah berbasis nilai Islam ini kemudian merefleksikan nilai keseimbangan dalam perspektif dunia dan akhirat, yaitu meraup kebahagian di dunia dengan mendapatkan profit halal dan ketenangan jiwa, dan perspektif akhirat dengan mengharapkan keridaan Allah swt. Dalam praktiknya, penyelesaian pembiayaan bermasalah yang dibangun berlandasakan konsepsi fikih muamalah oleh pihak developer berangkat dari niat ingin melaksanakan transaksi muamalah dengan skema syariah murni akan berimplikasi pada lahirnya keseimbangan kemanfaatan dengan meraih profit/laba di dunia dan pahala di akhirat karena hal ini bernilai ibadah.

${ }^{85}$ Janes O. Samwel, "An Assessment of the Impact of Performance Management on Employee and Organization Performance - Evidence from Selected Private Organizations in Tanzania”, International Journal of Human Resource Studies, 8 No. 3 (July 2018), h. 199.

${ }^{86}$ Satwinder Singh, Tamer K. Darwish, and Kristina Potocnik, "Measuring Organizational Performance: A Case for Subjective Measures”, British Journal of Management, 27 No. 1 (2016), h. 214.

${ }^{87}$ Nur Khusniyah Indrawati, dkk,"Manajemen Risiko Berbasis Spritual Islam", Jurnal Ekonomi dan Keuangan, 16 no. 2 (Juni 2012): h. 207. 
Relevansi PPR bernilai keseimbangan dalam proses penyelesaian pembiayaan oleh pihak developer terlihat dari penempatan 'niat' sebagai asas fundamental membangun bisnis properti syariah ini. Niat melakukan bisnis berlandaskan nilai-nilai syariah terwujud dalam proses muamalah yang mencoba menyeimbangkan antara tujuan duniawi dan tujuan ukhrawi serta menjauhi sifat individualistik. Hasilnya, income berupa materi dan imateriel dapat dirasakan oleh pihak developer. Skema PPR PT.

Tabel 4. Relevansi PPR Syariah Melahirkan Penyelesaian Bermasalah Bernilai Humanis Islami

\begin{tabular}{|c|c|c|c|c|c|}
\hline $\begin{array}{l}\text { Kualifikasi } \\
\text { Pembiayaan }\end{array}$ & Penanganan & Nilai & Implikasi & $\begin{array}{l}\text { Akumulasi } \\
\text { Kualifikasi } \\
\text { Pembiayaan }\end{array}$ & $\begin{array}{l}\text { Nilai dan } \\
\text { Implikasi }\end{array}$ \\
\hline \multirow[b]{2}{*}{$\begin{array}{c}\text { Kolektabilitas } \\
1\end{array}$} & $\begin{array}{l}\text { 1. Mengirim } \\
\text { surat } \\
\text { pemberitahuan, }\end{array}$ & & $\begin{array}{l}\text { Terbentuk } \\
\text { jejaring } \\
\text { supply }\end{array}$ & \multirow{6}{*}{$\begin{array}{l}\text { Niat } \\
\text { menerapkan } \\
\text { transaksi } \\
\text { mumalah } \\
\text { berbasis } \\
\text { syariah dalam } \\
\text { setiap } \\
\text { segmentasinya } \\
\text { terlihat dari } \\
\text { seluruh } \\
\text { penanganan } \\
\text { secara } \\
\text { keseluruhan }\end{array}$} & \multirow[b]{2}{*}{ 1. Keseimbangan } \\
\hline & $\begin{array}{l}\text { 2. Soft } \\
\text { connection } \\
\text { (kunjungan dan } \\
\text { musyawarah) }\end{array}$ & Ukhuwah & $\begin{array}{l}\text { chain yang } \\
\text { mengarah } \\
\text { kepada } \\
\text { win-win } \\
\text { solution }\end{array}$ & & \\
\hline \multirow[t]{2}{*}{$\begin{array}{c}\text { Kolektabilitas } \\
2\end{array}$} & $\begin{array}{l}\text { 1. Niat } \\
\text { melakukan } \\
\text { transaski tanpa } \\
\text { ribawi dan } \\
\text { mengakomodir } \\
\text { masyarakat } \\
\text { agar bisa } \\
\text { mendapatkan } \\
\text { rumah yang } \\
\text { mudah dan } \\
\text { terjangkau }\end{array}$ & \multirow[t]{2}{*}{ Maslahat } & \multirow[t]{2}{*}{$\begin{array}{l}\text { Melahirkan } \\
\text { atmosfir } \\
\text { muamalah } \\
\text { bernilai } \\
\text { Islami. }\end{array}$} & & \multirow{4}{*}{$\begin{array}{l}\text { 2. Berimplikasi } \\
\text { terhadap } \\
\text { pencapaian } \\
\text { kemaslahatan } \\
\text { duniawi yang } \\
\text { bernilai ukhrawi } \\
\text { dengan } \\
\text { mendapatkan } \\
\text { profit halal dan } \\
\text { ketenangan jiwa }\end{array}$} \\
\hline & $\begin{array}{l}\text { 2. Melakukan } \\
\text { restrukturisasi }\end{array}$ & & & & \\
\hline \multirow[t]{2}{*}{$\begin{array}{c}\text { Kolektabilitas } \\
3\end{array}$} & $\begin{array}{l}\text { 1. Mencari user } \\
\text { pengganti }\end{array}$ & & $\begin{array}{l}\text { Tercipta } \\
\text { prinsip ‘an } \\
\text { taradin }\end{array}$ & & \\
\hline & $\begin{array}{l}\text { 2. Melakukan } \\
\text { pengembalian } \\
\text { setoran user } \\
\text { secara } \\
\text { bertahap sesuai } \\
\text { proporsinya }\end{array}$ & Keadilan & $\begin{array}{l}\text { minkum' } \\
\text { antara } \\
\text { pihak } \\
\text { developer } \\
\text { dan pihak } \\
\text { user }\end{array}$ & & \\
\hline
\end{tabular}

Sumber: Data diolah tahun 2020

Wahana Persada Indonesia dalam penyelesaian pembiayaan memasuki domain tanggung jawab sosial merupakan hasil dari niat memberikan maslahat 
bagi para user, yang diimplementasikan dalam aktivitas tanggung jawab sosial perusahaan dalam menyelamatkan angsuran rumah user yang telah berjalan. Selain itu, mengubah paradigma dalam bisnis yang beranggapan bahwa keuntungan perusahaan atau kepentingan pribadi adalah segalanya dan mengabaikan unsur lainnya dalam tujuan perusahaan. Hal ini sejalan dengan pernyataan Herdjanto tentang prinsip pembiayaan Islami bahwa pada saat yang sama, uang difungsikan secara hakiki, yaitu sebagai alat untuk bertransaksi dan pengukur terhadap counter value berupa nilai barang, jasa, dan usaha ${ }^{88}$.

Prinsip dasar dari ekonomi dan pembiayaan Islam adalah untuk menciptakan kemaslahatan atau kesejahteraan masyarakat, dengan berpatokan pada kaidah fikih muamalah. Keempat nilai ini lahir sebagai hasil operasional manajemen perusahaan dalam praktik penyelesaian pembiayaan berbasis syariah. Hal ini menjadi referensi dalam konstruksi penanganan NPF berdasarkan etika bisnis Islam yang lahir dari akumulasi kemampuan operasionalisasi inteligensi dalam mengimplementasikan konsep fikih muamalah. Tahapan penyelesaian pembiayaan bermasalah yang diterapkan oleh pihak Developer Properti Syariah PT. Wahana Persada Indonesia merupakan hasil kolaborasi syariah dan konvensional dengan mengacu pada konsep fikih muamalah dalam setiap segmentasinya. Hasilnya, lahir sebuah atmosfer pembiayaan yang bernilai Islami yang sarat dengan kesan humanis dan tidak zalim.

\section{KESIMPULAN}

Mekanisme pembiayaan pada Developer Properti Syariah PT. Wahana Persada Indonesia dimulai dari survei lokasi, pembayaran BF sebagai tanda jadi dan pembayaran DP setelah fiksasi verifikasi dan interview. Selanjutnya user diminta melunasi angsuran hingga akhir masa tenor agar bisa melakukan AJB dan serah terima sertifikat kepemilikan rumah. Adapun relevansi nilai-nilai Islam dalam penyelesaian pembiayaan bermasalah pada PPR Developer Properti Syariah PT. Wahana Persada Indonesia dapat dilihat dari adanya nilai emaslahatan sebagai refleksi niat membangun bisnis real estate berdasarkan nilai-nilai syariat, niat inilah yang kemudian direalisasikan dalam penanganan pembiayaan memasuki kolektabilitas 2 (pertama).

Kedua, nilai ukhuwah yang tercermin dari praktik soft connection, di mana dalam tahap ini pihak developer melakukan pendekatan secara kekeluargaan dan senantiasa menjalin hubungan silaturahmi dengan pihak user. Selain itu, pihak developer juga memberikan berbagai kemudahan dalam hal penyelesaian pembiayaan kepada para user sebagai upaya menciptakan hubungan

${ }^{88}$ Hendy Herijanto, "Pripsip, Ketentuan, Dan Karakteristik Pembiyaan (Bank) Syariah", Jurnal Islaminomic, 5 No. 2 (Agustus 2016): h. 53. 
yang harmonis antara kedua pihak sebagai implementasi nilai ukhuwah. Ketiga, nilai keadilan yang tercermin dari bentuk penanganan pembiayaan memasuki kolektabilitas 3. Hal ini berimplikasi terhadap terciptanya sebuah transaski muamalah di atas prinsip 'an tarädin minkum. Keempat, nilai keseimbangan yang lahir dari niat pihak developer menjalankan bisnis tidak hanya untuk orientasi dunia semata, namun berusaha untuk menyeimbangkan antara tujuan dunia dan akhirat, di mana hal ini tergambar dari praktik muamalahnya dengan para user dan bentuk penyelesasian pembiayaannya secara keseluruhan.

\section{DAFTAR PUSTAKA}

Ahmad, al-Hanbalī. (1996). Musnad Imam Ahmad. 7, Tunish: Darul Garb alIslāmī

Alam, M. M., Akbar, C. S., Shahriar, S. M., \& Elahi, M. M. (2017). The Islamic Shariah principles for investment in stock market. Qualitative Research in Financial Markets, 9(2), 132-146. https://doi.org/10.1108/QRFM-09-20160029

Al-Bābartī, Muḥammad bin Muhammad. al-'Ināyah Syarh al-Hidāyah. 7, Beirut: Dar al-Fikr

Al-Bukhārī, Muḥammad bin Ismā'̄̄l bin Ibrāhīm. (1431/2010). Șaḥ̄h al-Bukhārī, Kairo: Dār Ibnu al-Jauz̄̄

Al-Fāsī, 'Allāl. (1414/1993). Maqāṣid al-Syarī'ah al-Islāmiyyah wa Makārimuha, Dumyāṭ: Maktabah al-Wahdah al-arabiyyah.

Al-Ghazali, Abū Hāmid Muḥammad. (1414/1993). al-Mushtasyfa Min 'Ilmi alUșūl. 1, Beirut: Dār al-kutub al-'Ilmiyyah

Al-Ḥākim, Muḥammad bin 'Abdillāh al-Naisābūrī. (1422/2002). al-Mustadrak 'Alā Șahịhain. 2, Beirut: Dar al-Kutub al-'Ilmiyyah

Al-Khațțāb, Muḥammad bin 'Abdirraḥmān al-Mālikī. (1431/2015). Mawāhibul Jalīl fì Syarh Mukhtaṣar al-Syaikh Khalīl. 4, Damaskus: Dar al-Riḍwān

Al-Nawaw̄ī, Abu Zakariyyā Yahyā bin Syaraf. (1412/1991). Rawdatu al-Ṭālibīn wa 'Umadatul Muftīn. 4, Riyad: al-Maktabah al-Islāmiyyah

Al-Syātịīī, Ibrāhīm bin Mūsā. (1418/1997). al-Muwāfaqāt fi Ușūl al-Syarī'ah. 2, Beirut: Dar al-Kutub al-Ilmiyyah

Al-Syāṭibī, Ibrāhīm bin Musā. (1429/2008). Al-I’tișām. 2, Kairo: Maktabah alTauhid

Al-Tirmizīe Muḥammad bin 'īsā. (1420/2000). Sunan al-Tirmizī. 1, Riyad: Maktabah al'Ma'ārif

Al-Zuhailī, Wahbah bin Muștafā. (1432/2011). al-Fiqh al-Islāmī wa Adillatuhu, Damaskus: Dar al-Fikr

Al-Zuhailī, Wahbah bin Muștafā. (1423/2002). al-Mu'āmalāt al-Māliyah alMu'āṣirah, Beirut: Dar al-Fikr 
Antonio, M. Syafi'i. (2001). Bank Syariah Dari Teori ke Praktik. Jakarta: Gema Insani Press

Ascarya. (2008). Akad dan Produk Bank Syariah. Jakarta: PT Raja Grafindo Persada

Aziah Abu Kasim, N. (2012). Disclosure of Shariah compliance by Malaysian takaful companies. Journal of Islamic Accounting and Business Research, 3(1), 20-38. https://doi.org/10.1108/17590811211216041

Damanhur, Albra, W., Syamni, G., \& Habibie, M. (2018). What is the Determinant of Non-Performing Financing in Branch Sharia Regional Bank in Indonesia. Emerald Reach Proceedings Series, 1, 265-271. https://doi.org/10.1108/978-1-78756-793-1-00081

Dewan Syariah Nasional Majelis Ulama Indonesia. (2003). Himpunan Fatwa Dewan Syariah Nasional, Jakarta: MUI Pusat

Farrukh, M. Z. (2012). Capitalism, Globalization \& Islamic Economic Sistim. Islamic Economics $\quad$ Journal, $\quad 1(1), \quad 73-81$. https://doi.org/10.21111/IEJ.V1I1.158

Fauzia, I. Y. (2018). Perilaku Pebisnis dan Wirausaha Muslim dalam Menjalankan Asas Transaksi Syariah. Jurnal Akuntansi Multiparadigma, 9(1), 38-56. https://doi.org/10.18202/jamal.2018.04.9003

Firmansyah, E. A., \& Gunardi, A. (2018). A New Paradigm in Islamic Housing: Non-Bank Islamic Mortgage. Al-Iqtishad: Jurnal Ilmu Ekonomi Syariah, 10(2), 313-324. https://doi.org/10.15408/aiq.v10i2.7274

Firmansyah, E. A., \& Indika, D. R. (2017). Kredit Pemilikan Rumah Syariah Tanpa Bank: Studi di Jawa Barat. Jurnal Manajemen Teori Dan Terapan. Journal of Theory and Applied Management, 10(3), 223. https://doi.org/10.20473/jmtt.v10i3.6541

Gilmore, A., Carson, D., \& O'Donnell, A. (2004). Small business ownermanagers and their attitude to risk. Marketing Intelligence \& Planning, 22(3), 349-360. https://doi.org/10.1108/02634500410536920

Hanif, M. (2019). Islamic mortgages: principles and practice. International Journal of Emerging Markets, 14(5), 1-30. https://doi.org/10.1108/IJOEM02-2018-0088

Hakim, L., \& Amelia, A. (2019). Pembiayaan Murabahah Pada Perbankan Syariah Dalam Perspektif Hukum di Indonesia. Jurnal Ekonomi Syariah Dan Filantropi Islam, 1(2), 212-223. https://doi.org/10.22236/alurban

Herijanto, H. (2016). Prinsip, Ketentuan, Dan Karakteristik Pembiayaan (Bank) Syariah. Islaminomic, $5(2)$, 267911. https://doi.org/http://garuda.ristekbrin.go.id/845974

Hidayah, M. R., Nawawi, K., \& Arif, S. (2018). Analisis Implementasi Akad Istishna Pembiayaan Rumah (Studi Kasus Developer Property Syariah 
Bogor). Jurnal Ekonomi Islam, 9(1), 1-12. https://doi.org/journal.uhamka.ac.id/index.php/jei

Ibnu Hajar, Aḥmad bin 'Alī al-Asqalānī. (1416/1995). Talkhīṣ al-Habīr fì Takhrīj Ahāàìs al-Rāfi' al-Kabīr. 3, Kairo: Muassasah al-Qurțūbah

Ibnu Humām, Muḥammad bin 'Abdil Wāḥid al-Askandarī. (1432/2010). Syarh Fathul Qadīr 'Alā Hidāyatu Syarh Bidāyatul Mubtad̄̄. 7, Beirut: Dar al-Fik

Ibnu Manżūr, Muḥammad bin Mukrim. (2010). Lisānul 'Arab. 7, Beirut: Dar Shadir

Ibnu Taimiyyah, Taqiyuddīn Abul 'Abbās. (1425/2004). Majmū' al-Fatāwa, 10, Madinah: Majma' Malik Fahd

Ibnu Qudāmah, Muwaffaquddīn. (1417/1997). al-Mugnī. 3, Dar 'Alam al-Kutub

Idri, \& Baru, R. (2017). The Principles of Islamic Economics and their Implementation in Indonesia. International Journal of Academic Research in Business and Social Sciences, 7(4), 331-343. https://doi.org/10.6007/ijarbss/v7-i4/2809

Idris, M. (2014). "Implementasi Pembiayaan Pemilikan Rumah (PPR) Syariah Studi Kasus Pada Griya Ar-Roya Di Kota Makassar". Tesis. Makassar: Ekonomi Syariah UIN Alauddin

Indrawati, N. K., Salim, U., Hadiwidjojo, D., \& Syam, N. (2012). Manajemen Risiko Berbasis Spritual Islam. Ekuitas: Jurnal Ekonomi Dan Keuangan, 16(2), 184-208. https://doi.org/10.24034/j25485024.y2012.v16.i2.2325

Iskandar, A., \& Aqbar, K. (2019). Reposisi Praktik Ekonomi Islam: Studi Kritis Praktik Ekonomi Islam di Indonesia. NUKHBATUL 'ULUM: Jurnal Bidang Kajian Islam, 5(1), 39-53. https://doi.org/10.36701/nukhbah.v5i1.68

Khadduri, Majid. (1984). The Islamic Conception of Justice. Maryland: The John Hopkins University Press

Khālidī, Ismā'îl. (2012). "al-Ḍawābit wa al-Qawā'id al-Syar'iyyah li alMu'āmalah al-Māliyyah al-Islāmiyyah”, al-Hay'ah al-Syar'iyyah li Bank alKuwayti al-Turki

Khan, M. A. (2018). Methodology of Islamic Economics From Islamic Teachings to Islamic Economics. Turkish Journal of Islamic Economics, 5(1), 34-63. https://doi.org/10.26414/tujise.2018.5.1

Kusumawati, N. N., Nuryartono, N., \& Beik, I. S. (2017). Analisis Pembiayaan dan Kredit Sektor Konstruksi di Indonesia: Studi Perbankan Syariah dan Konvensional. Jurnal Ekonomi Dan Kebijakan Pembangunan, 6(1), 21-40. https://doi.org/10.29244/jekp.6.1.21-40

Madjid, S. S. (2018). Penanganan Pembiyaan Bermasalah Pada Bank Syariah. Jurnal Hukum Ekonomi Syariah, 2(2), 95-109. https://doi.org/10.26618/jhes.v2i2.1618

Muslim, bin al-Ḥajjāj al-Naisābūrī. (1431/2010). Șaḥịh Muslim, Kairo: Dār Ibnu 
al-Jauzī

Mutawali, M., Rodoni, A., \& Said, M. Bin. (2019). Prevention Effectiveness of Non-Performing Financing in the Indonesian Islamic Bank. Etikonomi, 18(2), 259-274. https://doi.org/10.15408/etk.v18i2.11262

Nor, A. A. K. (2012). Disclosure of Shariah compliance by Malaysian takaful companies. Journal of Islamic Accounting and Business Research, 3(1), 2038. https://doi.org/10.1108/17590811211216041

Pradipta, H. A. R. M. S. (2018). Implementation of Istishna Contract in Sharia Developer (Case Study on Lukasya Land Property). International Journal of Science and Research (IJSR), 7(7), 357-360. https://doi.org/10.21275/ART20183867

Putritama, A. (2018). Penerapan Etika Bisnis Islam Dalam Industri Perbankan Syariah. Nominal, Barometer Riset Akuntansi Dan Manajemen, 7(1), 1-20. https://doi.org/10.21831/nominal.v7i1.19356

Rachamadi, U. (2009). Produk dan Akad Perbankan Syraiah di Indonesia. Cet. 1; Bandung: PT Citra Aditya Bakti

Rahman, R. A. (2016). Konsep Keadilan dalam Alquran. NUKHBATUL'ULUM: Jurnal Bidang Kajian Islam, 2(1), 167-175. https://doi.org/10.36701/nukhbah.v2i1.12

Rahman, Afazur. (1995). Doktrin Ekonomi Islam. Jilid 1, Yogyakarta: PT Dhana Bhakti Wakaf

Riana, D., dkk, (2008). Spiritual Entrepeneur. Bandung; MQS Publishing

Rivai, V., Permata, A. (2008). Islamic Financial Management. Raja Grafindo Persada: Jakarta

Saleh, M. (2011). Pasar Syariah dan Keseimbangan Harga. Media Syariah, 8(1), 21-35. https://doi.org/https://jurnal.arraniry.ac.id/index.php/medsyar/article/1740/1283

Samwel, J. O. (2018). An Assessment of the Impact of Performance Management on Employee and Organization Performance - Evidence from Selected Private Organizations in Tanzania. International Journal of Human Resource Studies, 8(3), 199-217. https://doi.org/10.5296/ijhrs.v8i3.13415

Singh, S., Darwish, T. K., \& Potočnik, K. (2016). Measuring Organizational Performance: A Case for Subjective Measures. British Journal of Management, 27(1), 214-224. https://doi.org/10.1111/1467-8551.12126

Sofyan, A. S., Said, S., \& Abdullah, M. W. (2019). Financing Risk Measurement With Maqashid Al-Sharia Qualitative Risk. Share: Jurnal Ekonomi Dan Keuangan Islam, 8(1), 1-30. https://doi.org/10.22373/share.v8i1.4355

Sohn, B. K., Thomas, S. P., Greenberg, K. H., \& Pollio, H. R. (2017). Hearing the Voices of Students and Teachers: A Phenomenological Approach to Educational Research. Qualitative Research in Education, 6(2), 121. 
https://doi.org/10.17583/qre.2017.2374

Sa'ad, al-Syasiri. (1426/2004). Syarh Al Manzhumatus Sa'diyah fil Qowa'id Al

Fiqhiyyah. Cet. 2; Kairo: Dar Kanuz Isybiliya

Undang-Undang RI Nomor 21 Tahun 2008 Tentang Perbankan Syariah dalam https://www.bphn.go.id/data/documents/92uu007. diakses pada 17 Desember 2019

Usanti, T. P. (2013). Transaksi Bank Syariah. Jakarta: PT Bumi Aksara

Usman, M. H., Aswar, A., \& Irawan, A. W. (2020). Syariat Islam dan Kemaslahatan Manusia di Era New Normal pada Kegiataan Keagamaan dan Pendidikan. FENOMENA, 12(1), 89-106.

https://doi.org/10.21093/fj.v12i1.2456

Yusof, K. S. (2014). Practices in Islamic Finance; Between Islamic Fiqh and Flexibilty of Syariah. Conference: Third Islamic Finance ConferenceAt: Sarajevo Bosnia, November, 1-17. http://www.researchgate.net/profile/ 54dd44270.pdf

Zakiyyuddin. (2006). Konsep Keadilan Dalam al-Qur'an. Disertasi, Yogyakarta: Pascasarjana UIN Sunan Kalijaga

Zulfikri, A., Sobari, A., \& Gustiawati, S. (2019). Strategi Penyelamatan Pembiayaan Bermasalah Pada Pembiayaan Murabahah Bank BNI Syariah Cabang Bogor. Al Maal: Journal of Islamic Economics and Banking, 1(1), 65. https://doi.org/10.31000/almaal.v1i1.1776

Zaroni, A. N. (2007). Bisnis Dalam Perspektif Islam (Telaah Aspek Keagamaan dalam Kehidupan Ekonomi). 4(2). https://doi.org/10.21093/mj.v4i2.507 